Article

Subscriber access provided by King Abdullah University of Science and Technology Library

\title{
Switching a Nanocluster Core from Hollow to Non-hollow
}

\author{
Megalamane S. Bootharaju, Chakra P Joshi, Mohammad J. Alhilaly, and Osman M. Bakr
}

Chem. Mater., Just Accepted Manuscript • DOI: 10.1021/acs.chemmater.5b05008 • Publication Date (Web): 24 Mar 2016

Downloaded from http://pubs.acs.org on March 29, 2016

\section{Just Accepted}

"Just Accepted" manuscripts have been peer-reviewed and accepted for publication. They are posted online prior to technical editing, formatting for publication and author proofing. The American Chemical Society provides "Just Accepted" as a free service to the research community to expedite the dissemination of scientific material as soon as possible after acceptance. "Just Accepted" manuscripts appear in full in PDF format accompanied by an HTML abstract. "Just Accepted" manuscripts have been fully peer reviewed, but should not be considered the official version of record. They are accessible to all readers and citable by the Digital Object Identifier (DOI®). "Just Accepted" is an optional service offered to authors. Therefore, the "Just Accepted" Web site may not include all articles that will be published in the journal. After a manuscript is technically edited and formatted, it will be removed from the "Just Accepted" Web site and published as an ASAP article. Note that technical editing may introduce minor changes to the manuscript text and/or graphics which could affect content, and all legal disclaimers and ethical guidelines that apply to the journal pertain. ACS cannot be held responsible for errors or consequences arising from the use of information contained in these "Just Accepted" manuscripts. 


\section{INTRODUCTION}

Control over size and structure of atomically precise nanoparticles $^{1-4}$ (NPs) has long been a subject of great interest. These compositionally precise NPs are usually designated by their distinct chemical formula similar to molecules, unlike average diameters that are used for describing the size of plasmonic NPs. As a result, these precise NPs are also called nanomolecules ${ }^{5}$ or nanoclusters ${ }^{6,7}$ (NCs). Metal NCs are considered a missing link between NPs and atoms, filling the gap between these two distinct size regimes. ${ }^{8} \mathrm{NCs}$ gained significant attention due to their unique optical ${ }^{9-13}$ and physicochemical ${ }^{1,14}$ properties as well as intriguing electronic and redox behavior ${ }^{15,16}$. These characteristics made NCs a new class of functional materials for applications in catalysis, ${ }^{17,}{ }^{18}$ sensing, ${ }^{19}$ biology, ${ }^{3,6}$ energy, ${ }^{20}$ and environment ${ }^{21}$.

The typical routes for metal NC synthesis are: i) direct reduction of metal precursors in the presence of desired ligands, ${ }^{22-28}$ ii) postsynthetic ligand-exchange (LE), ${ }^{29-35}$ and iii) metal-exchange ${ }^{15,}{ }^{36-44}$. Among these methods, LE has recently been widely adopted for preparing novel gold $\mathrm{NCs}^{42-44}$. The use of LE in other metal systems, such as silver is rare and its mechanism remains unexplored and poorly understood. ${ }^{29}$, 30 Particularly in silver, LE is exclusively based on a biphasic approach, where the starting and the final products move between two immiscible phases. Although biphasic (e.g., aqueous and organic) LE was shown to be a highly promising strategy to synthesize NCs due to the ease of extracting the final NC product, ${ }^{29}, 3^{\circ}$ the abrupt NC transformations in these biphasic systems preclude the use of standard characterization tools such as mass spectrometry and optical spectroscopy to elucidate the LE mechanisms and the intricate cluster transformation steps involved. As a result, the LE mechanism in several NCs remains unknown. Revealing the complete details of the reaction pathways of LE in atomically precise NCs provides a view of the fundamental processes of LE chemistry of NPs that plasmonic NPs ${ }^{45}$ and quantum dots ${ }^{46}$ with their heterogeneous size distribution cannot afford.

In this work, we designed a single phase LE reaction to understand the step-by-step conversion of $\mathrm{Ag}_{44}(\mathrm{SR})_{30} \mathrm{NCs}$ to $\mathrm{Ag}_{25}(\mathrm{SR})_{18} \mathrm{NCs}$, and vice versa, where studying the interconversion of these NCs was challenging in a biphasic LE. The single phase $\mathrm{LE}$ of $\mathrm{Ag}_{44}(\mathrm{SPhF})_{30}$ clusters (-SPhF: 4-fluorobenzenethiolate) with 2,4dimethylbenzenethiol $\left(\mathrm{HSPhMe}_{2}\right)$ initially led to the partial LE and then complete LE. After complete LE, the $\mathrm{Ag}_{44}$ experienced structural distortions to form $\mathrm{Ag}_{25}\left(\mathrm{SPhMe}_{2}\right)_{18}$ and intermediate $\mathrm{NCs}$ of sizes larger than $\mathrm{Ag}_{44}$. On the other hand, the formation of $\mathrm{Ag}_{44}(\mathrm{SPhF})_{30}$ from the $\mathrm{Ag}_{25}\left(\mathrm{SPhMe}_{2}\right)_{18}$ was observed to occur in a different pathway, wherein $\mathrm{Ag}_{25}$ dimerize and rearrange to reproduce the $\mathrm{Ag}_{44}$ along with the similar sized intermediates aforementioned. These intermediates and the nature of ligands appear to dictate the formation of hollow $\mathrm{Ag}_{44}$ and non-hollow $\mathrm{Ag}_{25}$ cores. Experimental results shed light into the LE mechanism and the effect of ligand structure 
in governing the size and the structure of the final LE product.

\section{EXPERIMENTAL SECTION}

\section{Chemicals}

All chemicals of analytical grade were purchased from Sigma-Aldrich and used without further purification. Silver nitrate $\left(\mathrm{AgNO}_{3}\right)$, 4-mercaptobenzoic acid $(\mathrm{HSPhCOOH})$, sodium borohydride $\left(\mathrm{NaBH}_{4}\right)$, tetraphenylphosphonium bromide $\left(\mathrm{PPh}_{4} \mathrm{Br}\right), \quad 2,4^{-}$ dimethylbenzenethiol $\quad\left(\mathrm{HSPhMe}_{2}\right), \quad$ 2,4difluorobenzenethiol $\left(\mathrm{HSPhF}_{2}\right), 2$,4-dichlorobenzenethiol $\left(\mathrm{HSPhCl}_{2}\right)$, 4-methylbenzenethiol (HSPhMe), 4fluorobenzenethiol $(\mathrm{HSPhF})$, citric acid, sodium hydroxide pellets, triethylamine, methanol, acetonitrile (HPLC grade), dimethylformamide (DMF), and dichloromethane (DCM).

\section{Synthesis of $\mathrm{Ag}_{44}(\mathrm{SPhCOOH})_{30} \mathrm{NCs}$}

$7.5 \mathrm{mg}$ of $\mathrm{HSPhCOOH}$ was dissolved in $5 \mathrm{~mL}$ of deionized (DI) water using $400 \mu \mathrm{L}$ of $1 \mathrm{M} \mathrm{NaOH}$. To this solution, 7 mg of $\mathrm{AgNO}_{3}$ in $1 \mathrm{~mL}$ of DI water was added and stirred for 20 minutes. After that, $2 \mathrm{mg}$ of $\mathrm{NaBH}_{4}$ in $1 \mathrm{~mL}$ of DI water was added. The light yellow Ag-thiolate solution turned dark red over 45 minutes indicating the formation of Ag NCs. The as-prepared clusters were precipitated and cleaned with excess methanol.

\section{Transformation of $\mathrm{Ag}_{44}(\mathrm{SPhCOOH})_{30} \mathrm{NCs}$ to $\mathrm{Ag}_{25}\left(\mathrm{SPhMe}_{2}\right)_{18} \mathrm{NCs}$}

$5 \mathrm{~mL}$ of methanolic $\mathrm{PPh}_{4} \mathrm{Br}(1 \mathrm{mg} / \mathrm{mL})$ solution was added to $5 \mathrm{~mL}$ of DCM that containing $5 \mu \mathrm{L}$ of $\mathrm{HSPhMe}_{2}$. After that, $5 \mathrm{~mL}$ of aqueous $\mathrm{Ag}_{44}(\mathrm{SPhCOOH})_{30} \mathrm{NCs}(5 \mathrm{mg} / \mathrm{mL})$ was added and stirred for 2-3 minutes. The DCM layer that containing LE product was separated, dried, and then washed with methanol.

\section{Conversion of $\mathrm{Ag}_{25}\left(\mathrm{SPhMe}_{2}\right)_{18} \mathrm{NCs}$ to $\mathrm{Ag}_{44}(\mathrm{SPhCOOH})_{30} \mathrm{NCs}$}

$5 \mathrm{~mL}$ of $\mathrm{Ag}_{25}\left(\mathrm{SPhMe}_{2}\right)_{18}$ solution (2 $\mathrm{mg} / \mathrm{mL}$ DCM) was added to $5 \mathrm{~mL}$ of alkaline aqueous $\mathrm{HSPhCOOH}$ (10 $\mathrm{mg} / \mathrm{mL}$ ) and stirred. The colorless aqueous layer turned pale pink indicating the LE of NCs.

\section{LE of $\mathrm{Ag}_{44}(\mathrm{SPhF})_{30} \mathrm{NCs}$ with various thiols}

The $\mathrm{Ag}_{44}(\mathrm{SPhF})_{30} \mathrm{NCs}$ were synthesized as per the literature $^{11}$ and also, see Supporting Information (SI) for details. About $5 \mathrm{mg}$ of $\mathrm{Ag}_{44}(\mathrm{SPhF})_{30} \mathrm{NCs}$ in $5 \mathrm{~mL}$ of DCM was stirred with $5 \mu \mathrm{L}$ (2.3 times excess, in mmol, compared to the total ligand amount in the starting material) of a desired thiol $\mathrm{HSPhMe}_{2}, \mathrm{HSPhF}_{2}$, or $\mathrm{HSPhCl}_{2}$. The progress of LE reaction was examined using optical spectroscopy and mass spectrometry.

\section{LE of $\mathrm{Ag}_{25}\left(\mathrm{SPhMe}_{2}\right)_{18} \mathrm{NCs}$ with HSPhF}

$5 \mathrm{mg}$ of $\mathrm{Ag}_{25}\left(\mathrm{SPhMe}_{2}\right)_{18}$ in $5 \mathrm{~mL}$ of DCM was reacted with $5 \mu \mathrm{L}$ (2.8 times excess, in mmol, compared to the total ligand amount in the starting material) of HSPhF and the formation of the LE products were tracked using UV-vis spectroscopy and mass spectrometry.

\section{Characterization}

UV-vis absorption spectra were collected using a JAZZ spectrophotometer (Ocean Optics). Electrospray ionization mass spectra (ESI MS) of NCs were acquired using a Bruker MicroTOF-II. Organic-soluble NCs were dissolved in a DCM+acetonitrile mixture and electrosprayed. The $\mathrm{Ag}_{44}(\mathrm{SPhCOOH})_{30}$ was dissolved in DMF after protonation with citric acid. The typical instrument parameters used were: mass range 100-10,oooDa; flow rate: $600 \mu \mathrm{L} / \mathrm{h}$; capillary voltage $3.5-4.0 \mathrm{kV}$; source temperature $80-120{ }^{\circ} \mathrm{C}$; dry gas $0.2-0.4 \mathrm{~L} / \mathrm{min}$, and nebulizer gas $0.3-0.5$ bar.

\section{RESULTS AND DISCUSSION}

We initially developed a biphasic, aqueous-organic, LE approach to convert $\mathrm{Ag}_{44}(\mathrm{SR})_{30}$ to $\mathrm{Ag}_{25}(\mathrm{SR})_{18}$, and vice versa. A purified aqueous solution of $\mathrm{Ag}_{44}(\mathrm{SPhCOOH})_{30} \mathrm{NCs}$ that exhibit characteristic UV-vis and mass spectra (Figures 1 and $\mathrm{S} 1$ in $\mathrm{SI}$ ) was used as a starting point for the LE reaction. After two minutes of $\mathrm{LE}$ of $\mathrm{Ag}_{44}(\mathrm{SPhCOOH})_{30}$ with $\mathrm{HSPhMe}_{2}$, the colorless DCM layer turned dark brown indicating a successful phase transfer, while the aqueous layer became colorless (Figure $1 \mathrm{~A}$ inset). The absorption spectrum (Figure $1 \mathrm{~A}$ ) of cleaned dark brown solution displays unique features different from that of parent $\mathrm{Ag}_{44}$ indicating the transformation of the $\mathrm{Ag}_{44}$ cluster to a new size cluster. All of these UV-vis characteristics of new cluster are found to exactly match with those of recently reported $\mathrm{Ag}_{25}(\mathrm{SR})_{18}{ }^{27}$ cluster inferring the LE product was likely $\mathrm{Ag}_{25}\left(\mathrm{SPhMe}_{2}\right)_{18} \mathrm{NC}$.
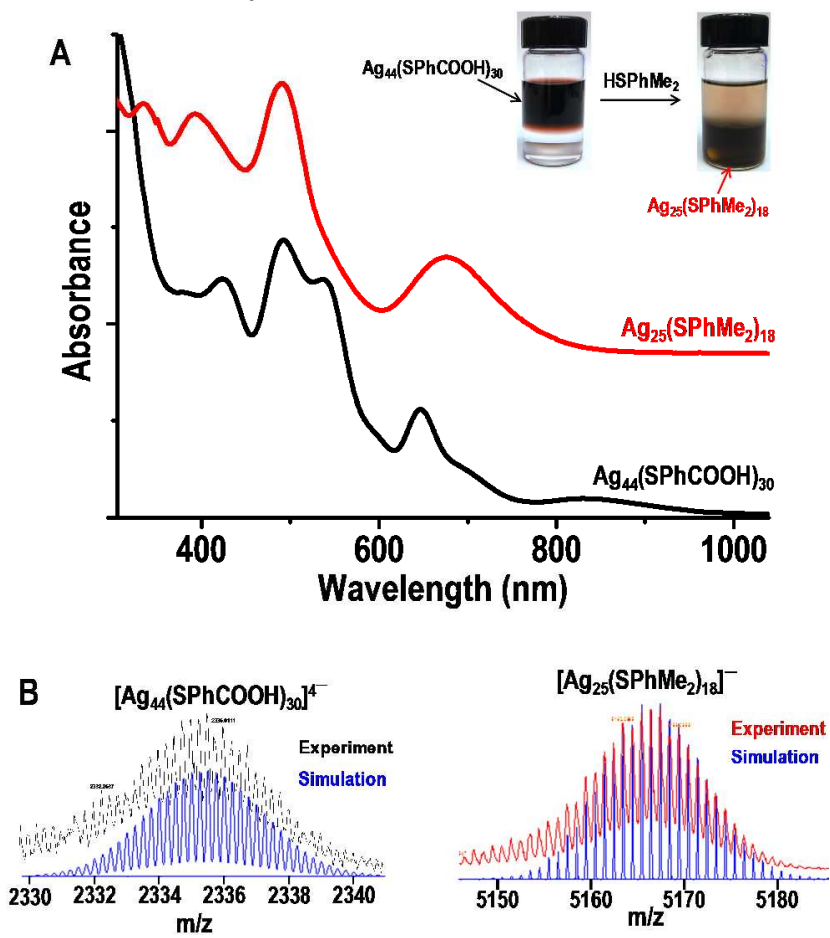

Figure 1. (A) UV-vis of $\mathrm{Ag}_{44}(\mathrm{SPhCOOH})_{30}$ and its $\mathrm{HSPhMe}_{2}-$ exchanged product (red trace). Inset: photographs of $\mathrm{Ag}_{44}(\mathrm{SPhCOOH})_{30} \mathrm{LE}$ from the top aqueous layer to the bot- 
tom DCM layer. (B) ESI MS of $\left[\operatorname{Ag}_{44}(\mathrm{SPhCOOH})_{30}\right]^{4^{-}}$and its LE product $\left[\mathrm{Ag}_{25}\left(\mathrm{SPhMe}_{2}\right)_{18}\right]^{-}$that are compared with their simulated mass spectra (see Figure $S_{1}$ for full-range mass spectra).

This assignment was further confirmed by highresolution ESI MS of the LE product, which shows a single peak at $\mathrm{m} / \mathrm{z} 5167$ (Figure $\mathrm{S} 1 \mathrm{~B}$ ) corresponding to a molecular formula of $\left[\mathrm{Ag}_{25}\left(\mathrm{SPhMe}_{2}\right)_{18}\right]^{-} \mathrm{NCs}$. The simulated $\left[\mathrm{Ag}_{25}\left(\mathrm{SPhMe}_{2}\right)_{18}\right]^{-}$mass spectrum and the experimental data are in excellent agreement (Figure $1 \mathrm{~B}$ ). The presence of a single peak of $\mathrm{Ag}_{25}$ and the absence of peaks of $\mathrm{HSPhCOOH}$ or its Ag-complexes are indicative of the formation of pure $\mathrm{Ag}_{25}\left(\mathrm{SPhMe}_{2}\right)_{18}$ from $\mathrm{Ag}_{44}(\mathrm{SPhCOOH})_{30}$. Similarly, $\mathrm{Ag}_{44}$ can be recovered by exchanging $\mathrm{SPhMe}_{2}$ ligands of $\mathrm{Ag}_{25}$ with $\mathrm{HSPhCOOH}$ (Figure S2). Fascinatingly, $\mathrm{Ag}_{44}{ }^{10,11}$ and $\mathrm{Ag}_{25}{ }^{27} \mathrm{NCs}$ possess unique core structures in addition to differences in core charge and the arrangement of ligands. The $\left[\mathrm{Ag}_{44}(\mathrm{SR})_{30}\right]^{4^{-}}$cluster consists of a hollow icosahedral $\mathrm{Ag}_{12}$ core encapsulated in a dodecahedral $\mathrm{Ag}_{20}$ that is stabilized by six three-dimensional (3D) $\mathrm{Ag}_{2}(\mathrm{SR})_{5}$ units. $^{10,}{ }^{11} \mathrm{On}$ the other hand, the $\left[\mathrm{Ag}_{25}(\mathrm{SR})_{18}\right]^{-}$ cluster has a non-hollow icosahedral $\mathrm{Ag}_{13}$ core protected with six $1 \mathrm{D} \mathrm{Ag}_{2}(\mathrm{SR})_{3}$ units. $^{27}$

Although the biphasic LE shown here is a promising method for obtaining truly single sized $\mathrm{Ag}_{25}\left(\mathrm{SPhMe}_{2}\right)_{18}$ in good yield (8o $\left.\mathrm{wt} \%\right)$, the rapidity and dual phase nature of the approach hinder the investigation of the intricate reaction pathway that the clusters traversed to transform from a particle with a hollow core to a one with a non-hollow core, and vice versa. To elucidate the steps of this intriguing size and structural conversions through which these NCs occurred, we designed a single phase LE that enabled tracking the step-by-step changes in the reaction by ESI MS and optical absorption spectroscopy.

\section{The Conversion of $\mathrm{Ag}_{44}(\mathrm{SPhF})_{30} \mathrm{NCs}$ to $\mathrm{Ag}_{25}(\mathrm{SPhMe})_{18} \mathrm{NCs}$ in a Single Phase LE}

Since $\mathrm{Ag}_{44}(\mathrm{SPhCOOH})_{30}$ was soluble only in aqueous and polar solvents, while the incoming ligand $\mathrm{HSPhMe}_{2}$, and product $\mathrm{Ag}_{25}\left(\mathrm{SPhMe}_{2}\right)_{18}$ were soluble only in non-polar organic solvents, we searched for the set of ligands and resultant clusters that all could be solubilized in a single solvent. Therefore, we substituted SPhCOOH with SPhF, which is also a suitable ligand for $\mathrm{Ag}_{44}$. However, $\mathrm{HSPhF}$, $\mathrm{Ag}_{44}(\mathrm{SPhF})_{30}, \mathrm{HSPhMe}_{2}$, and $\mathrm{Ag}_{25}\left(\mathrm{SPhMe}_{2}\right)_{18}$ could all be solubilized in DCM. Notably, we optimized the concentration of the reactants in the single phase LE so that it occurs over the course of hours instead of seconds or minutes. Consequently, we were able to monitor the LE processes using mass spectrometry (Figure 2) and absorption spectroscopy (Figure 3).

In overall, single phase LE transformation of $\mathrm{Ag}_{44}$ to $\mathrm{Ag}_{25}$ can be categorized into four stages as described below.

Stage 1: Within 30 minutes of $\mathrm{LE}, \mathrm{Ag}_{44}(\mathrm{SPhF})_{30}$ was found to exchange $18 \mathrm{SPhF}$ ligands with incoming $18 \mathrm{SPhMe}_{2}$ ligands to produce a predominant product of $\mathrm{Ag}_{44}(\mathrm{SPhF})_{12}\left(\mathrm{SPhMe}_{2}\right)_{18}$ and a less predominant product of a nearly completely exchanged nanocluster of $\mathrm{Ag}_{44}(\mathrm{SPhF})_{1}(\mathrm{SPhMe})_{29}$. Note that we also observed several minor products with compositions $\mathrm{Ag}_{44}(\mathrm{SPhF})_{30}$ ${ }_{m}\left(\mathrm{SPhMe}_{2}\right)_{\mathrm{m}}$, where $\mathrm{m}<18$ and $\mathrm{m}>18$ (Figure $\mathrm{S}_{3} \mathrm{~A}$ ). The optical features of the transforming clusters display the same characteristics of an intact $\mathrm{Ag}_{44}$ structure but with a slight red-shift in $644 \mathrm{~nm}$ peak. After $1 \mathrm{~h}$, nearly equal concentrations of $\mathrm{Ag}_{44}(\mathrm{SPhF})_{12}\left(\mathrm{SPhMe}_{2}\right)_{18}$ and $\mathrm{Ag}_{44}(\mathrm{SPhF})_{1}\left(\mathrm{SPhMe}_{2}\right)_{29}$ were observed as indicated by their mass peak intensities. The remnant absorption features of $\mathrm{Ag}_{44}$ are observed with the changes in peaks at 833, 537 and $644 \mathrm{~nm}$, implying also the presence of an intact $\mathrm{Ag}_{44}$ core.

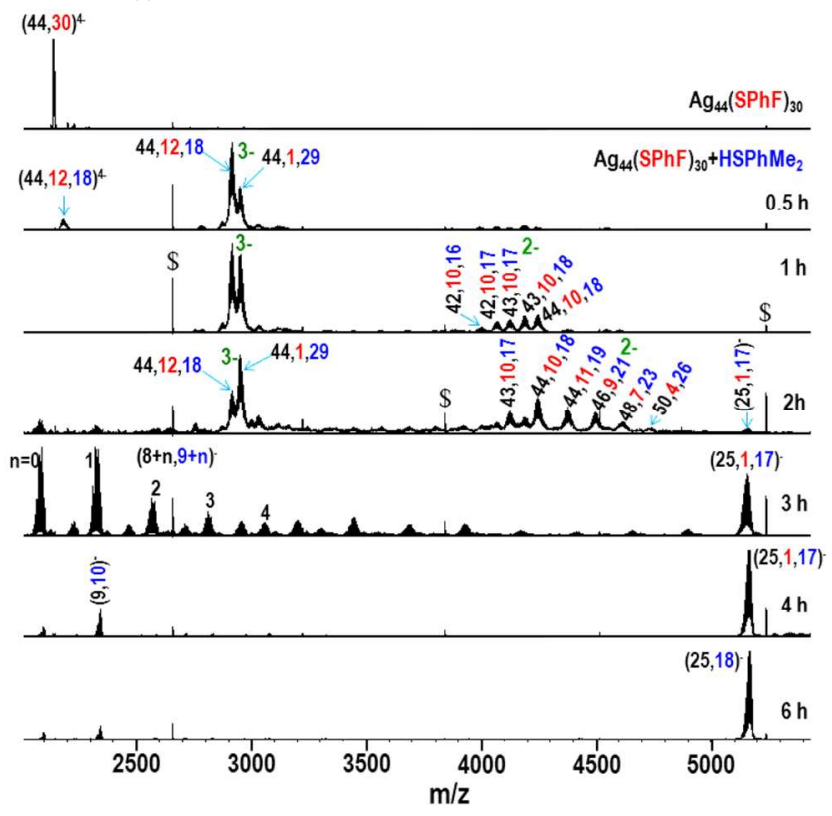

Figure 2. Time-dependent ESI MS study of $\left[\mathrm{Ag}_{44}(\mathrm{SPhF})_{30}\right]^{4-}$ $\mathrm{LE}$ with $\mathrm{HSPhMe}_{2}$. The numbers with black, red, and blue color correspond to the number of $\mathrm{Ag}$ atoms, SPhF, and $\mathrm{SPhMe}_{2}$ ligands, respectively. The numbers in green represent the charge of the clusters. Sharp peaks labeled with ' $\$$ ' are unknown impurity artifacts in the mass-spectrometer without silver isotopic pattern, which are also present in the spectrum of a pure HPLC-grade DCM control. Mass spectral data reveal the conversion of $\mathrm{Ag}_{44}$ to $\mathrm{Ag}_{25}$ through intermediate NCs.

Stage 2: After $2 \mathrm{~h}, \mathrm{Ag}_{44}(\mathrm{SPhF})_{1}\left(\mathrm{SPhMe}_{2}\right)_{29}$ becomes the most predominant product. The presence of $29 \mathrm{SPhMe}_{2}$ ligands on $\mathrm{Ag}_{44}$ at this stage would have created structural distortion that are also reflected in the absorption spectrum in which the $644 \mathrm{~nm}$ peak is broadened (denoted with asterisk in Figure 3) and shifted to $658 \mathrm{~nm}$. The selective formation of two predominant LE products i.e., $\mathrm{Ag}_{44}(\mathrm{SPhF})_{12}\left(\mathrm{SPhMe}_{2}\right)_{18}$ and $\mathrm{Ag}_{44}(\mathrm{SPhF})_{1}\left(\mathrm{SPhMe}_{2}\right)_{29}$ (Figure $\mathrm{S}_{3}$ ), despite the myriad of other possible compositional possibilities is peculiar and requires some rationalization. Note that the $\mathrm{Ag}_{44}$ metal core is preserved until $29 \mathrm{SPhF}$ of the original $\operatorname{Ag}_{44}(\mathrm{SPhF})_{30}$ is replaced with $\mathrm{SPhMe}_{2}$. Recall also that there are six $3 \mathrm{D} \quad \mathrm{Ag}_{2}(\mathrm{SPhF})_{5}$ motifs in $\mathrm{Ag}_{44}(\mathrm{SPhF})_{30}$ structure $^{11}$ (Figure $\left.\mathrm{S}_{4} \mathrm{~A}\right)$. The first predominant product would have thus formed by replacing three SPhF from each motif of $\mathrm{Ag}_{44}(\mathrm{SPhF})_{30}$ with three $\mathrm{SPhMe}_{2}$ 
(Figure $\left.\mathrm{S}_{4} \mathrm{~B}\right)$ giving rise to $\mathrm{Ag}_{44}(\mathrm{SPhF})_{12}\left(\mathrm{SPhMe}_{2}\right)_{18}$. At this stage, three of $\mathrm{SPhMe}_{2}$ ligands are far apart to have little inter-ligand interactions and do not perturb the $\mathrm{Ag}_{44}$ structure. However, with passing of time, another predominant product $\mathrm{Ag}_{44}(\mathrm{SPhF})_{1}\left(\mathrm{SPhMe}_{2}\right)_{29}$ forms likely by replacing all $\mathrm{SPhF}$ ligands of $\mathrm{Ag}_{44}(\mathrm{SPhF})_{12}\left(\mathrm{SPhMe}_{2}\right)_{18}$. At this stage, five $\mathrm{SPhMe}_{2}$ ligands are present (Figure $\mathrm{S}_{4} \mathrm{C}$ ) in a motif. This situation leads not only to increased steric repulsions between bulky methyl groups, but also enhanced inter-ligand pi-pi interactions in $3 \mathrm{D}$ motifs of $\mathrm{Ag}_{44}$ that destabilizes the $\mathrm{Ag}_{44}$ structure.

Stage 3: After 2-3 h of LE, the distorted $\mathrm{Ag}_{44}(\mathrm{SPhF})_{1}\left(\mathrm{SPhMe}_{2}\right)_{29}$ seems to dissociate disproportionately to form mixed ligand $\mathrm{Ag}_{25}(\mathrm{SPhF})_{1}\left(\mathrm{SPhMe}_{2}\right)_{17}$ (Figure $\mathrm{S}_{5}$ ) while releasing fragments such as $\operatorname{Ag}_{\mathrm{n}}\left(\mathrm{SPhMe}_{2}\right)_{\mathrm{n}+1}+\mathrm{Ag}_{19-\mathrm{n}}, \mathrm{n} \leq 11$ as observed in the mass spectrum (Figure S6). Some of these released fragments and the liberated SPhFs' (during exchange with $\mathrm{SPhMe}_{2}$ in the previous stages) may further get absorbed by remaining $\mathrm{Ag}_{44}(\mathrm{SPhF})_{1}\left(\mathrm{SPhMe}_{2}\right)_{29}$ to yield higher nuclearity intermediates such as $\left[\mathrm{Ag}_{46}(\mathrm{SPhF})_{9}\left(\mathrm{SPhMe}_{2}\right)_{21}\right]^{2-}$, $\left[\mathrm{Ag}_{48}(\mathrm{SPhF})_{7}\left(\mathrm{SPhMe}_{2}\right)_{23}\right]^{2-}$, and $\left[\mathrm{Ag}_{50}(\mathrm{SPhF})_{4}\left(\mathrm{SPhMe}_{2}\right)_{26}\right]^{2-}$ (Figure 2 and $\mathrm{S}_{7}$ ).

Stage 4: After 3-4 h, previously formed intermediates $\mathrm{Ag}_{46}, \mathrm{Ag}_{48}$, and $\mathrm{Ag}_{50}$ were decomposed exclusively to an $\mathrm{Ag}_{25}(\mathrm{SPhF})_{1}(\mathrm{SPhMe})_{17}$ product as indicated by the gradual increase in its corresponding mass peak intensity (Figure 2). This size focusing process that is observed at $3-4 \mathrm{~h}$ is also reflected in the absorption spectra indicated by the characteristic features of $\mathrm{Ag}_{25}$ cluster. Finally, due to the presence of excess $\mathrm{HSPhMe}_{2}$ in the reaction, the mixed ligand $\mathrm{Ag}_{25}(\mathrm{SPhF})_{1}\left(\mathrm{SPhMe}_{2}\right)_{17}$ eventually gets transformed into a pure ligand system i.e., $\left[\mathrm{Ag}_{25}\left(\mathrm{SPhMe}_{2}\right)_{18}\right]^{-}$with $\sim 80 \%$ purity. The change in overall charge from 4- $\left(\right.$ in $\left.\mathrm{Ag}_{44}\right)$ to 1(in $\mathrm{Ag}_{25}$ ) occurred to impart the electronic stability to the final $\mathrm{Ag}_{25}$ product (Figure $\mathrm{S}_{5}$ ), which is governed by the shell-closing ${ }^{1}$ rule $\left[25^{-18}-(-1)=8 e^{-}\right]$.

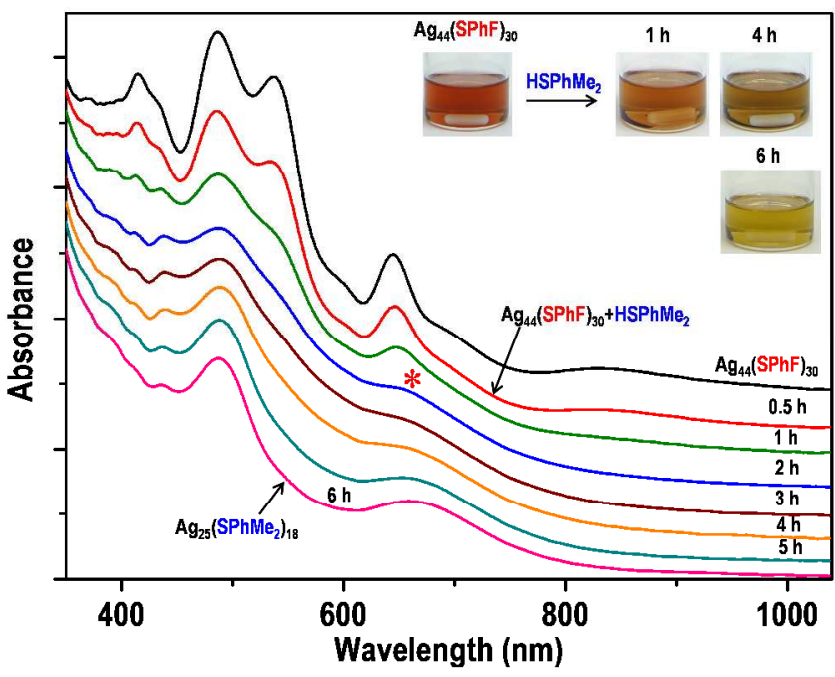

Figure 3. Time-dependent absorption study of $\mathrm{Ag}_{44}(\mathrm{SPhF})_{30}$ $\mathrm{LE}$ with $\mathrm{HSPhMe}_{2}$. The asterisk on blue spectrum indicates the broadening and red-shifting of the $644 \mathrm{~nm}$ peak. Inset: photographs showing the $\mathrm{Ag}_{44}(\mathrm{SPhF})_{30} \mathrm{LE}$ reaction with $\mathrm{HSPhMe}_{2}$ as a function of time. A clear color change from red $\mathrm{Ag}_{44}$ to yellow indicates the formation of a new product $\mathrm{Ag}_{25}$.

\section{The formation of $\mathrm{Ag}_{44}(\mathrm{SPhF})_{30} \mathrm{NCs}$ from $\mathrm{Ag}_{25}(\mathrm{SPhMe})_{18} \mathrm{NCs}$ in a Single Phase LE}

$\mathrm{Ag}_{25}\left(\mathrm{SPhMe}_{2}\right)_{18}$ in DCM was reacted with $\mathrm{HSPhF}$ and the time-dependent mass and absorption spectra (Figures 4 and S8) were acquired to elucidate the LE mechanism. The complete formation of $\mathrm{Ag}_{44}$ from $\mathrm{Ag}_{25}$ may also similarly be divided into four stages which we briefly summarize below.

Unlike $\operatorname{Ag}_{44}(\mathrm{SPhF})_{30}, \mathrm{Ag}_{25}\left(\mathrm{SPhMe}_{2}\right)_{18}$ undergoes rapid LE (typically within 60 minutes) with the incoming HSPhF. As a result, the first three stages seem to occur within 2-10 minutes. In the first stage, five $\mathrm{SPhMe}_{2}$ of $\mathrm{Ag}_{25}\left(\mathrm{SPhMe}_{2}\right)_{18}$ were exchanged with five $\mathrm{HSPhF}$ to form a mixed ligand $\left[\mathrm{Ag}_{25}\left(\mathrm{SPhMe}_{2}\right)_{13}(\mathrm{SPhF})_{5}\right]^{2-}$ (Figure $4 \mathrm{~A}$ and S9A). Formation of this mixed ligand $\mathrm{Ag}_{25}$ would have removed special orientation ${ }^{27}$ of $\mathrm{SPhMe}_{2}$ ligands on $\mathrm{Ag}_{25}$, which were originally of $1 \mathrm{D} \mathrm{Ag}_{2}\left(\mathrm{SPhMe}_{2}\right)_{3}$ motifs. The incorporation of five SPhF ligands in $\mathrm{ID}$ motifs would push them to rearrange into $3 \mathrm{D}$ motifs, as $\mathrm{SPhF}^{11}$ prefers $3 \mathrm{D}$ to ${ }_{1 D}$ motifs. As a result, in the second stage, $\left[\mathrm{Ag}_{25}\left(\mathrm{SPhMe}_{2}\right)_{13}(\mathrm{SPhF})_{5}\right]^{2-}$ species undergo dimerization, similar to $\mathrm{Au}_{25}$ ploymerization, ${ }^{47}$ to produce an intermediate product $\left[\mathrm{Ag}_{50}\left(\mathrm{SPhMe}_{2}\right)_{26}(\mathrm{SPhF})_{10}\right]^{3-}$, which further forms $\left[\mathrm{Ag}_{50}\left(\mathrm{SPhMe}_{2}\right)_{26}(\mathrm{SPhF})_{9}\right]^{3^{-}}$upon losing one $\mathrm{SPhF}$ ligand (Figure S9B). Here, the dimerization of $\left[\mathrm{Ag}_{25}(\mathrm{SPhMe})_{13}(\mathrm{SPhF})_{5}\right]^{2-}$ seems to follow an isoelectronic addition $^{7}$ path giving rise to an electronically stable $\left[\mathrm{Ag}_{50}\left(\mathrm{SPhMe}_{2}\right)_{26}(\mathrm{SPhF})_{9}\right]^{3^{-}}$intermediate with a close shell configuration $\left[50-35^{-}(-3)=18 e^{-}\right]$. In the third stage, this intermediate undergoes disproportionation to form two sets of new intermediates $\left[\mathrm{Ag}_{47+n}\left(\mathrm{SPhMe}_{2}\right)_{26}(\mathrm{SPhF})_{6+\mathrm{n}}\right]^{3^{-}}$, $\mathrm{n}=\mathrm{O}-6$, and $\left[\mathrm{Ag}_{41+\mathrm{n}}(\mathrm{SPhMe})_{24}(\mathrm{SPhF})_{3+\mathrm{n}}\right]^{2-}, \mathrm{n}=\mathrm{O}-7$ along with the mixed ligand $\mathrm{Ag}_{44}$ i.e., $\left[\mathrm{Ag}_{44}\left(\mathrm{SPhMe}_{2}\right)_{24}(\mathrm{SPhF})_{6}\right]^{2-}$. Finally, in the fourth stage (around 45 minutes), remaining ${ }_{24} \mathrm{SPhMe}_{2}$ are replaced by SPhF ligands to produce a one ligand cluster i.e., $\left[\operatorname{Ag}_{44}(\mathrm{SPhF})_{30}\right]^{4-}$. This final product, with $\sim 80 \%$ purity, is found to be electronically stable with a core charge of 4 - contributing to a closed shell configuration $\left[44-30-(-4)=18 e^{-}\right]$. These compositional changes in stages 1 to 4 were also manifested in the immediate disappearance of the characteristic $\operatorname{Ag}_{25}$ absorption features and appearance of $\mathrm{Ag}_{44}$ signature peaks (Figure ${ }_{4} \mathrm{~B}$ ). Noteworthy, similar intermediate cluster sizes i.e., $\mathrm{Ag}_{46}$, $\mathrm{Ag}_{48}$, and $\mathrm{Ag}_{50}$ were identified during $\mathrm{Ag}_{44}$ to $\mathrm{Ag}_{25}$ interconversion (Figures 2 and 4). These intermediates appear to act as a switching state between the hollow and nonhollow core clusters, and were driven to either core state depending on the type of excess ligand in the reaction. Important observations during interconversion between $\mathrm{Ag}_{44}$ and $\mathrm{Ag}_{25}$ are depicted in Scheme 1. 

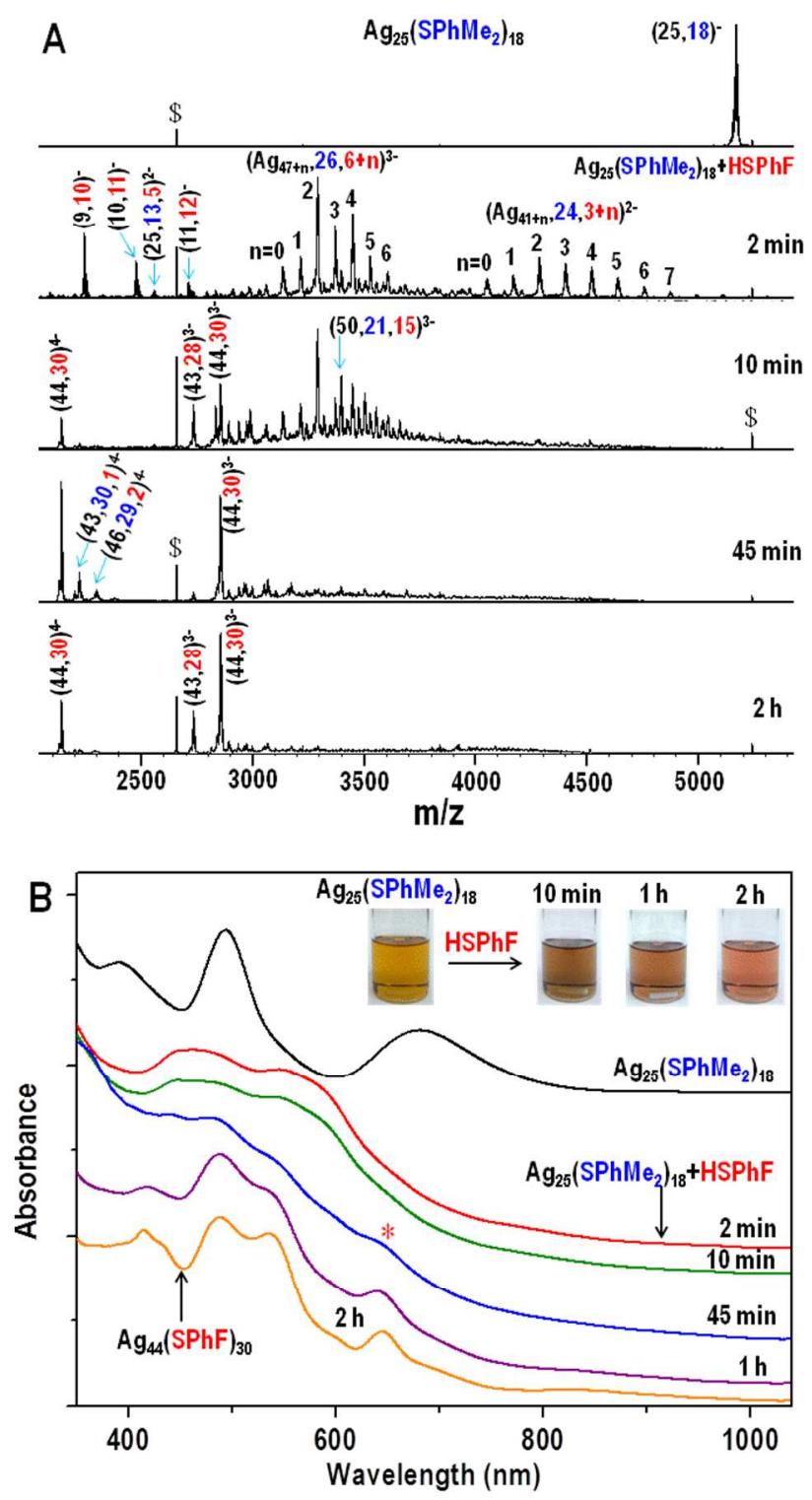

Figure 4. (A) Time-dependent ESI MS and (B) UV-vis study of $\mathrm{Ag}_{25}\left(\mathrm{SPhMe}_{2}\right)_{18}$ LE with $\mathrm{HSPhF}$. Sharp peaks labeled with '\$' are unknown impurity artifacts in the mass-spectrometer without silver isotopic pattern, which are also present in the spectrum of a pure HPLC-grade DCM control. Red asterisk in $\mathrm{B}$ (on blue curve) shows the appearance of $\mathrm{Ag}_{44}$ features. Inset: photographs of $\mathrm{Ag}_{25}\left(\mathrm{SPhMe}_{2}\right)_{18} \mathrm{LE}$ as a function of time. Color change from orange $\mathrm{Ag}_{25}$ to red indicates the formation of $\mathrm{Ag}_{44}$ cluster.

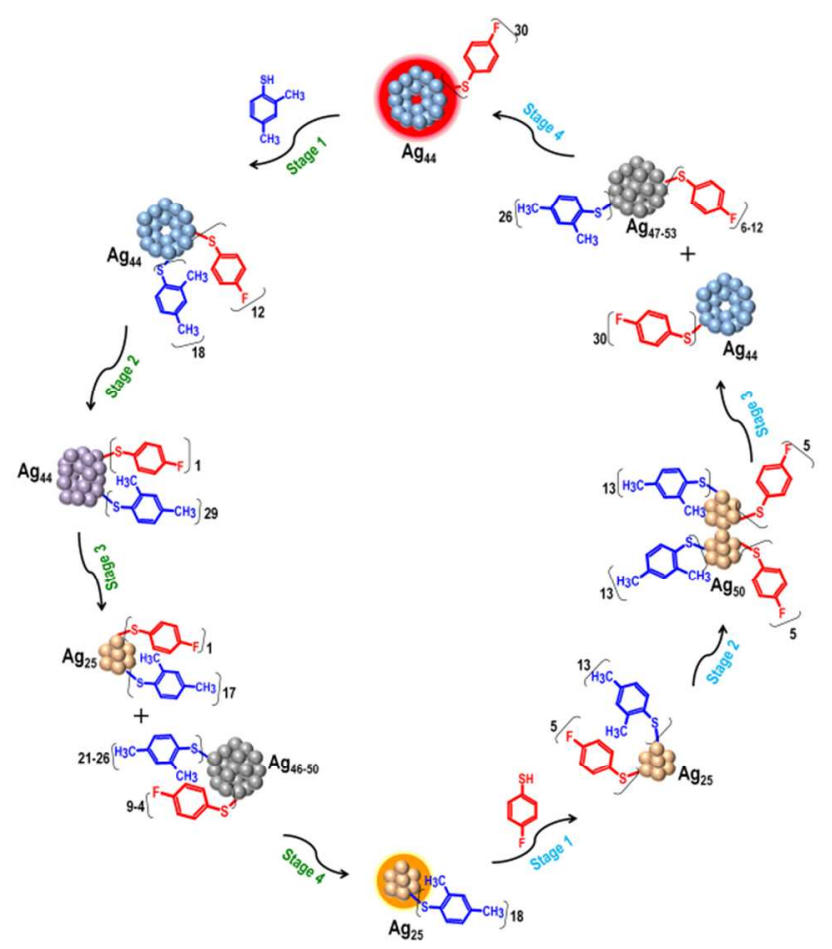

Scheme 1. Interconversion between $\mathrm{Ag}_{44}(\mathrm{SPhF})_{30}$ (inside red circle) and $\mathrm{Ag}_{25}\left(\mathrm{SPhMe}_{2}\right)_{18}$ (inside yellow circle) via LE. All color spheres: Ag atoms. Left half cycle: stage 1, partial LE; stage 2, nearly complete LE; stage 3, disproportionation; and stage 4, size focusing. Right half cycle: stage 1, partial LE; stage 2, dimerization; stage 3 , disproportionation; and stage 4 , size focusing.

From our experimental observations (see Scheme 1), the presence of electron releasing (e.g., methyl) or withdrawing (e.g., $\mathrm{Cl}$, and $\mathrm{F}$ ) groups in the ligand along with the steric hindrance that is provided by these groups while orienting themselves on a cluster are predicted to be crucial in determining the final cluster size during LE. To further examine this deduction, we designed additional experiments by choosing specific ligands such as $\mathrm{HSPhF}_{2}$ and $\mathrm{HSPhCl}_{2}$, in which the bulky methyl groups of $\mathrm{HSPhMe}_{2}$ are replaced by less bulky $\mathrm{F}$ and $\mathrm{Cl}$ atoms. Surprisingly, we observed an intact $\mathrm{Ag}_{44}$ after complete LE of $\mathrm{Ag}_{44}(\mathrm{SPhF})_{30}$ with $\mathrm{HSPhF}_{2}$ and $\mathrm{HSPhCl}_{2}$ (Figure Sio). On the other hand, the use of HSPhMe (4methylbenzenethiol), with only one bulky methyl group, led to the decomposition of $\mathrm{Ag}_{44}$ after $\mathrm{LE}$, clearly indicating the significant effect of ligand bulkiness along with the electronic effects of the substituent in defining the nature of core and the size of metal clusters.

\section{CONCLUSION}

We successfully designed a single phase LE reaction to completely elucidate the step-by-step transformation of $\mathrm{Ag}_{44}(\mathrm{SR})_{30} \mathrm{NCs}$ to $\mathrm{Ag}_{25}(\mathrm{SR})_{18} \mathrm{NCs}$, and vice versa, where tracking the interconversion of these NCs was problematic in prior biphasic LE approaches. Our detailed investigations of the LE with unprecedented atomic detail reveal that the $\mathrm{Ag}_{44}$ to $\mathrm{Ag}_{25}$ transformation occurs via a disproportionation mechanism, whereas its reverse occurs through an uncommon dimerization prior to dispropor- 
tionation. Both the forward and the reverse LE processes are highly sensitive to the incoming ligand geometry and the nature of substituents in the ligand, whose effects are clearly manifested not only in the protecting-shell but also at the heart of the metal core. The presented single phase LE strategy and the fundamental understanding of NCs size- and structure-tuning provides a platform for exploring the interconversion of other nanoparticle systems and stimulates theoretical research in predicting the nanoparticle conversion reactions.

\section{ASSOCIATED CONTENT}

\section{Supporting Information}

ESI MS characterization of LE reactions of $\mathrm{Ag}_{44}(\mathrm{SPhF})_{30}$ and $\mathrm{Ag}_{25}\left(\mathrm{SPhMe}_{2}\right)_{18}$; UV-vis spectra and ESI MS of various thiols reactions with $\operatorname{Ag}_{44}(\mathrm{SPhF})_{30}$. This material is available free of charge via the Internet at http://pubs.acs.org.

\section{AUTHOR INFORMATION}

\section{Corresponding Author}

*E-mail: osman.bakr@kaust.edu.sa

\section{Author Contributions}

The manuscript was written through contributions of all authors.

\section{Notes}

The authors declare no competing financial interest.

\section{ACKNOWLEDGMENTS}

Financial support for this work was provided by KAUST.

\section{REFERENCES}

1. Joshi, C. P.; Bootharaju, M. S.; Bakr, O. M. Tuning Properties in Silver Clusters. J. Phys. Chem. Lett. 2015, 6, 3023-3035.

2. Jin, R. Atomically precise metal nanoclusters: stable sizes and optical properties. Nanoscale 2015, 7, 1549-1565.

3. Mathew, A.; Pradeep, T. Noble Metal Clusters: Applications in Energy, Environment, and Biology. Part. Part. Syst. Charact. 2014, 31, 1017-1053.

4. Kurashige, W.; Niihori, Y.; Sharma, S.; Negishi, Y. Recent Progress in the Functionalization Methods of ThiolateProtected Gold Clusters. J. Phys. Chem. Lett. 2014, 5, 41344142.

5. Dass, A.; Theivendran, S.; Nimmala, P. R.; Kumara, C.; Jupally, V. R.; Fortunelli, A.; Sementa, L.; Barcaro, G.; Zuo, X.; Noll, B. C. $\mathrm{Au}_{133}(\mathrm{SPh}-\mathrm{tBu})_{52}$ Nanomolecules: X-ray Crystallography, Optical, Electrochemical, and Theoretical Analysis. J. Am. Chem. Soc. 2015, 137, 4610-4613.

6. Zheng, K.; Yuan, X.; Goswami, N.; Zhang, Q.; Xie, J. Recent advances in the synthesis, characterization, and biomedical applications of ultrasmall thiolated silver nanoclusters. RSC Adv. 2014, 4, 60581-60596.

7. Luo, Z.; Nachammai, V.; Zhang, B.; Yan, N.; Leong, D. T.; Jiang, D.-e.; Xie, J. Toward Understanding the Growth Mechanism: Tracing All Stable Intermediate Species from Reduction of $\mathrm{Au}(\mathrm{I})$-Thiolate Complexes to Evolution of $\mathrm{Au}_{25}$ Nanoclusters. J. Am. Chem. Soc. 2014, 136, 10577-10580.

8. Negishi, Y.; Nobusada, K.; Tsukuda, T. GlutathioneProtected Gold Clusters Revisited: Bridging the Gap between Gold(I)-Thiolate Complexes and Thiolate-Protected Gold Nanocrystals. J. Am. Chem. Soc. 2005, 127, 5261-5270.
9. Bakr, O. M.; Amendola, V.; Aikens, C. M.; Wenseleers, W.; Li, R.; Dal Negro, L.; Schatz, G. C.; Stellacci, F. Silver Nanoparticles with Broad Multiband Linear Optical Absorption. Angew. Chem. Int. Ed. 2009, 121, 6035-6040.

10. Desireddy, A.; Conn, B. E.; Guo, J.; Yoon, B.; Barnett, R. N.; Monahan, B. M.; Kirschbaum, K.; Griffith, W. P.; Whetten, R. L.; Landman, U.; Bigioni, T. P. Ultrastable silver nanoparticles. Nature 2013, 501, 399-402.

11. Yang, H.; Wang, Y.; Huang, H.; Gell, L.; Lehtovaara, L.; Malola, S.; Häkkinen, H.; Zheng, N. All-thiol-stabilized $\mathrm{Ag}_{44}$ and $\mathrm{Au}_{12} \mathrm{Ag}_{32}$ nanoparticles with single-crystal structures. Nat. Commun. 2013, 4, 2422.

12. Udayabhaskararao, T.; Pradeep, T. New Protocols for the Synthesis of Stable $\mathrm{Ag}$ and Au Nanocluster Molecules. J. Phys. Chem. Lett. 2013, 4, 1553-1564.

13. Pelton, M.; Tang, Y.; Bakr, O. M.; Stellacci, F. Long-Lived Charge-Separated States in Ligand-Stabilized Silver Clusters. J. Am. Chem. Soc. 2012, 134, 11856-11859.

14. Som, A.; Samal, A. K.; Udayabhaskararao, T.; Bootharaju, M. S.; Pradeep, T. Manifestation of the Difference in Reactivity of Silver Clusters in Contrast to Its Ions and Nanoparticles: The Growth of Metal Tipped Te Nanowires. Chem. Mater. 2014, 26, 3049-3056.

15. Wu, Z. Anti-Galvanic Reduction of Thiolate-Protected Gold and Silver Nanoparticles. Angew. Chem. Int. Ed. 2012, 51, 2934-2938.

16. Choi, J. P.; Fields-Zinna, C. A.; Stiles, R. L.; Balasubramanian, R.; Douglas, A. D.; Crowe, M. C.; Murray, R. W. Reactivity of $\left[\mathrm{Au}_{25}\left(\mathrm{SCH}_{2} \mathrm{CH}_{2} \mathrm{Ph}\right)_{18}\right]^{1-}$ Nanoparticles with Metal Ions. J. Phys. Chem. C 2010, 114, 15890-15896.

17. Wang, S.; Jin, S.; Yang, S.; Chen, S.; Song, Y.; Zhang, J.; Zhu, M. Total structure determination of surface doping $\left[\mathrm{Ag}_{46} \mathrm{Au}_{24}(\mathrm{SR})_{32}\right]\left(\mathrm{BPh}_{4}\right)_{2}$ nanocluster and its structure-related catalytic property. Sci. Adv. 2015, 1, e1500441.

18. Fang, J.; Li, J.; Zhang, B.; Yuan, X.; Asakura, H.; Tanaka, T.; Teramura, K.; Xie, J.; Yan, N. The support effect on the size and catalytic activity of thiolated $\mathrm{Au}_{25}$ nanoclusters as precatalysts. Nanoscale 2015, 7, 6325-6333.

19. Bootharaju, M. S.; Pradeep, T. Investigation into the Reactivity of Unsupported and Supported $\mathrm{Ag}_{7}$ and $\mathrm{Ag}_{8}$ Clusters with Toxic Metal Ions. Langmuir 2011, 27, 8134-8143.

20. Chen, Y.-S.; Kamat, P. V. Glutathione-Capped Gold Nanoclusters as Photosensitizers. Visible Light-Induced Hydrogen Generation in Neutral Water. J. Am. Chem. Soc. 2014, 136, 6075-6o82.

21. Bootharaju, M. S.; Deepesh, G. K.; Udayabhaskararao, T.; Pradeep, T. Atomically precise silver clusters for efficient chlorocarbon degradation. J. Mater. Chem. A 2013, 1, 611-620.

22. Udayabhaskararao, T.; Bootharaju, M. S.; Pradeep, T. Thiolate-protected $\mathrm{Ag}_{32}$ clusters: mass spectral studies of composition and insights into the Ag-thiolate structure from NMR. Nanoscale 2013, 5, 9404-9411.

23. Kumar, S.; Bolan, M. D.; Bigioni, T. P. Glutathione-Stabilized Magic-Number Silver Cluster Compounds. J. Am. Chem. Soc. 2010, 132, 13141-13143.

24. AbdulHalim, L. G.; Ashraf, S.; Katsiev, K.; Kirmani, A. R.; Kothalawala, N.; Anjum, D. H.; Abbas, S.; Amassian, A.; Stellacci, F.; Dass, A.; Hussain, I.; Bakr, O. M. A scalable synthesis of highly stable and water dispersible $\operatorname{Ag}_{44}(\mathrm{SR})_{30}$ nanoclusters. J. Mater. Chem. A 2013, 1, 10148-10154.

25. AbdulHalim, L. G.; Bootharaju, M. S.; Tang, Q.; Del Gobbo, S.; AbdulHalim, R. G.; Eddaoudi, M.; Jiang, D.-e.; Bakr, O. M. $\mathrm{Ag}_{29}(\mathrm{BDT})_{12}(\mathrm{TPP})_{4}$ : A Tetravalent Nanocluster. J. Am. Chem. Soc. 2015, 137, 11970-11975.

26. Yan, J.; Su, H.; Yang, H.; Malola, S.; Lin, S.; Häkkinen, H.; Zheng, N. Total Structure and Electronic Structure Analysis 
of Doped Thiolated Silver $\left[\mathrm{MAg}_{24}(\mathrm{SR})_{18}\right]^{2-}(\mathrm{M}=\mathrm{Pd}, \mathrm{Pt})$ Clusters. J. Am. Chem. Soc. 2015, 137, 11880-11883.

27. Joshi, C. P.; Bootharaju, M. S.; Alhilaly, M. J.; Bakr, O. M. $\left[\mathrm{Ag}_{25}(\mathrm{SR})_{18}\right]^{-}$: The "Golden" Silver Nanoparticle. J. Am. Chem. Soc. 2015, 137, 11578-11581.

28. Wickramasinghe, S.; Atnagulov, A.; Yoon, B.; Barnett, R. N.; Griffith, W. P.; Landman, U.; Bigioni, T. P. $\mathrm{M}_{3} \mathrm{Ag}_{17}(\mathrm{SPh})_{12}$ Nanoparticles and Their Structure Prediction. J. Am. Chem. Soc. 2015, 137, 11550-11553.

29. AbdulHalim, L. G.; Kothalawala, N.; Sinatra, L.; Dass, A.; Bakr, O. M. Neat and Complete: Thiolate-Ligand Exchange on a Silver Molecular Nanoparticle. J. Am. Chem. Soc. 2014, 136, 15865-15868.

3o. Bootharaju, M. S.; Burlakov, V. M.; Besong, T. M. D.; Joshi, C. P.; AbdulHalim, L. G.; Black, D. M.; Whetten, R. L.; Goriely, A.; Bakr, O. M. Reversible Size Control of Silver Nanoclusters via Ligand-Exchange. Chem. Mater. 2015, 27, 4289-4297.

31. Jupally, V. R.; Dass, A. Synthesis of $A_{130}(S R)_{50}$ and $A_{130-}$ ${ }_{x} \mathrm{Ag}_{\mathrm{x}}(\mathrm{SR})_{50}$ nanomolecules through core size conversion of larger metal clusters. Phys. Chem. Chem. Phys. 2014, 16, 10473-10479.

32. Zeng, C.; Chen, Y.; Li, G.; Jin, R. Magic Size $\mathrm{Au}_{64}\left(\mathrm{~S}-\mathrm{c}-\mathrm{C}_{6} \mathrm{H}_{11}\right)_{32}$ Nanocluster Protected by Cyclohexanethiolate. Chem. Mater. 2014, 26, 2635-2641.

33. Nimmala, P. R.; Dass, A. $\mathrm{Au}_{99}(\mathrm{SPh})_{42}$ Nanomolecules: Aromatic Thiolate Ligand Induced Conversion of $\mathrm{Au}_{144}\left(\mathrm{SCH}_{2} \mathrm{CH}_{2} \mathrm{Ph}\right)_{60}$. J. Am. Chem. Soc. 2014, 136, 17016-17023.

34. Zeng, C.; Chen, Y.; Das, A.; Jin, R. Transformation Chemistry of Gold Nanoclusters: From One Stable Size to Another. J. Phys. Chem. Lett. 2015, 6, 2976-2986.

35. Fernando, A.; Aikens, C. M. Ligand Exchange Mechanism on Thiolate Monolayer Protected $\mathrm{Au}_{25}(\mathrm{SR})_{18}$ Nanoclusters. J. Phys. Chem. C 2015, 119, 20179-20187.

36. Bootharaju, M. S.; Joshi, C. P.; Parida, M. R.; Mohammed, O. F.; Bakr, O. M. Templated Atom-Precise Galvanic Synthesis and Structure Elucidation of a $\left[\mathrm{Ag}_{24} \mathrm{Au}(\mathrm{SR})_{18}\right]^{-}$Nanocluster. Angew. Chem. Int. Ed. 2016, 55, 922-926.

37. Yang, S.; Wang, S.; Jin, S.; Chen, S.; Sheng, H.; Zhu, M. A metal exchange method for thiolate-protected tri-metal
$\mathrm{M}_{1} \mathrm{Ag}_{\mathrm{x}} \mathrm{Au}_{24-\mathrm{x}}(\mathrm{SR})_{18}{ }^{\mathrm{O}}(\mathrm{M}=\mathrm{Cd} / \mathrm{Hg})$ nanoclusters. Nanoscale 2015, 7, 10005-10007.

38. Wang, S.; Song, Y.; Jin, S.; Liu, X.; Zhang, J.; Pei, Y.; Meng, X.; Chen, M.; Li, P.; Zhu, M. Metal Exchange Method Using Au25 Nanoclusters as Templates for Alloy Nanoclusters with Atomic Precision. J. Am. Chem. Soc. 2015, 137, 4018-4021.

39. Udayabhaskararao, T.; Sun, Y.; Goswami, N.; Pal, S. K.; Balasubramanian, K.; Pradeep, T. Ag $A_{7} u_{6}$ : A 13-Atom Alloy Quantum Cluster. Angew. Chem. Int. Ed. 2012, 51, 2155-2159.

40. Krishnadas, K. R.; Ghosh, A.; Baksi, A.; Chakraborty, I.; Natarajan, G.; Pradeep, T. Inter-cluster reactions between $\mathrm{Au}_{25}(\mathrm{SR})_{18}$ and $\mathrm{Ag}_{44}(\mathrm{SR})_{30}$. J. Am. Chem. Soc. 2016, 138, 140148.

41. Yao, C.; Lin, Y.-j.; Yuan, J.; Liao, L.; Zhu, M.; Weng, L.-h.; Yang, J.; Wu, Z. Mono-cadmium vs Mono-mercury Doping of $\mathrm{Au}_{25}$ Nanoclusters. J. Am. Chem. Soc. 2015, 137, 15350-15353.

42. Zeng, C.; Liu, C.; Pei, Y.; Jin, R. Thiol Ligand-Induced Transformation of $\mathrm{Au}_{38}\left(\mathrm{SC}_{2} \mathrm{H}_{4} \mathrm{Ph}\right)_{24}$ to $\mathrm{Au}_{36}(\mathrm{SPh}-t \mathrm{Bu})_{24}$. ACS Nano 2013, 7, 6138-6145.

43. Shichibu, Y.; Negishi, Y.; Tsukuda, T.; Teranishi, T. LargeScale Synthesis of Thiolated $\mathrm{Au}_{25}$ Clusters via Ligand Exchange Reactions of Phosphine-Stabilized Aun Clusters. J. Am. Chem. Soc. 2005, 127, 13464-13465.

44. McKenzie, L. C.; Zaikova, T. O.; Hutchison, J. E. Structurally Similar Triphenylphosphine-Stabilized Undecagolds, $\mathrm{Au}_{11}\left(\mathrm{PPh}_{3}\right)_{7} \mathrm{Cl}_{3}$ and $\left[\mathrm{Au}_{11}\left(\mathrm{PPh}_{3}\right)_{8} \mathrm{Cl}_{2}\right] \mathrm{Cl}$, Exhibit Distinct Ligand Exchange Pathways with Glutathione. J. Am. Chem. Soc. 2014, 136, 13426-13435.

45. Alkilany, A. M.; Yaseen, A. I. B.; Park, J.; Eller, J. R.; Murphy, C. J. Facile phase transfer of gold nanoparticles from aqueous solution to organic solvents with thiolated poly(ethylene glycol). RSC $A d v$. 2014, 4, 52676-52679.

46. Dubois, F.; Mahler, B.; Dubertret, B.; Doris, E.; Mioskowski, C. A Versatile Strategy for Quantum Dot Ligand Exchange. J. Am. Chem. Soc. 2007, 129, 482-483.

47. De Nardi, M.; Antonello, S.; Jiang, D.-e.; Pan, F.; Rissanen, K.; Ruzzi, M.; Venzo, A.; Zoleo, A.; Maran, F. Gold Nanowired: A Linear $\left(\mathrm{Au}_{25}\right)_{\mathrm{n}}$ Polymer from $\mathrm{Au}_{25}$ Molecular Clusters. ACS Nano 2014, 8, 8505-8512.

\section{Table of Contents}
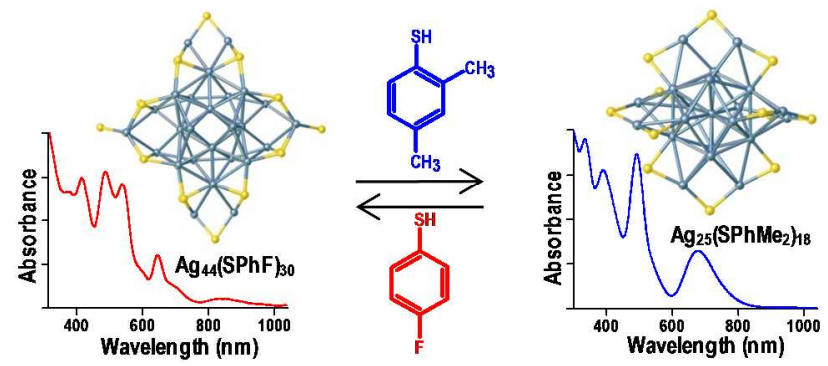